\title{
Grain, oil, and protein production on soybean stems and branches under reduced densities
}

\author{
Flávia Werner ${ }^{1 *} \oplus$, Marcelo Augusto de Aguiar e Silva ${ }^{1} \oplus$, André Sampaio Ferreira ${ }^{1} \oplus$, \\ Claudemir Zucareli ${ }^{1}$, Alvadi Antonio Balbinot Junior ${ }^{2}$

\footnotetext{
1 Universidade Estadual de Londrina, Londrina, PR, Brasil. E-mail: flawerner6@gmail.com; aguiaresilva@uel.br; andresampaioferreira@gmail.com; claudemircca@uel.br

${ }^{2}$ Embrapa Soja, Londrina, PR, Brasil. E-mail: alvadi.balbinot@embrapa.br
}

ABSTRACT: The reduction of sowing density is a strategy that aims to reduce production costs with no losses in grain yield. This study aimed to evaluate the yield components and contents of protein and oil in grains from branches and stems of two soybean cultivars as a function of the reduction in sowing density. The experiments were conducted in two growing seasons (2016/17 and 2017/18) in Londrina, PR, Brazil. Two soybean cultivars were evaluated: BRS 1010 IPRO and NS 5959 IPRO. The experimental design was completely randomized blocks in a split-plot scheme, with five replications. Plots consisted of five sowing densities $(100,80,60,40$, and $20 \%$ of that indicated by the cultivar breeder) and subplots consisted of two plant strata (branches and stems). The number of pods $\mathrm{m}^{-2}$ and grain, protein, and oil yield increased in the branches and decreased in the stems with a decrease in sowing density. The number of grains per pod is higher in the stems than in the branches, regardless of the cultivar. The protein content in the grains is higher in the branches than in the stems for the cultivar BRS 1010 IPRO and decreased with a reduction in sowing density. The thousand-grain weight of the cultivar NS 5959 IPRO decreased with a reduction in sowing density. The oil content in the grains was not influenced by the studied factors.

Key words: Glycine max L.; grain yield; spatial arrangement of plants

\section{Produção de grãos, óleo e proteína nas hastes e ramos da soja sob densidades reduzidas}

RESUMO: A redução da densidade de semeadura é uma estratégia que visa reduzir o custo de produção sem prejuízo à produtividade de grãos. $\mathrm{O}$ objetivo do trabalho foi avaliar os componentes do rendimento e os teores de proteína e óleo em grãos oriundos de ramos e hastes de duas cultivares de soja em função da redução da densidade de semeadura. Os experimentos foram conduzidos em duas safras (2016/17 e 2017/18) em Londrina, PR. Foram avaliadas duas cultivares de soja: BRS 1010 IPRO e NS 5959 IPRO. O delineamento experimental foi em blocos completos casualizados em esquema de parcelas subdivididas, com 5 repetições. Nas parcelas foram alocadas cinco densidades de semeadura (100, 80, 60, 40 e $20 \%$ do indicado pelo obtentor das cultivares) e, nas subparcelas, dois estratos de plantas (ramos e hastes). Com o decréscimo na densidade de semeadura, o número de vagens $\mathrm{m}^{-2}$ e as produtividades de grãos, de proteína e de óleo aumentam nos ramos e diminuem nas hastes. $O$ número de grãos por vagem é maior nas hastes em comparação com os ramos, independentemente da cultivar. $O$ teor de proteína nos grãos é maior nos ramos em relação às hastes para a cultivar BRS 1010 IPRO e diminui com a redução da densidade de semeadura. Para a cultivar NS 5959 IPRO, a massa de mil grãos diminui com a redução da densidade de semeadura. $O$ teor de óleo nos grãos não é influenciado pelos fatores estudados.

Palavras-chave: Glycine max L.; produtividade de grãos; arranjo espacial de plantas

\footnotetext{
* Flávia Werner - E-mail: flawerner6@gmail.com (Corresponding author)

Associate Editor: Adônis Moreira
} 


\section{Introduction}

The adoption of biotechnological events and the use of new technologies have added high value to soybean seeds, thus increasing the production costs of crops. An alternative to reduce the consumption of seeds and, consequently, the total production cost is to use the minimum sowing density that allows the maximum grain yield to be reached (Board \& Kahlon, 2013; Gaspar \& Conley, 2015). The sowing density necessary to obtain the optimum yield is, in general, lower than that indicated by the cultivar breeders when the environmental conditions (e.g., temperature, humidity, solar radiation, and photoperiod) are favorable to plant growth (De Bruin \& Pedersen, 2008; Corassa et al., 2018).

Several studies have pointed out the possibility of reducing the soybean sowing density without reducing yield, increasing the economic return (Lee et al., 2008; Büchling et al., 2017). It is possible due to the high phenotypic plasticity of soybean plants (Cox \& Cherney, 2011; Balbinot Junior et al., 2018), which alter the yield components when their architecture and morphology are changed, providing equivalent yield even in a wide range of sowing densities (De Bruin \& Pedersen, 2008; Balbinot Junior et al., 2016).

Soybean plants at low densities tend to emit a high number of branches and increase their size, providing an increase in the number of pods per plant, which generates higher production per plant, thus maintaining the crop grain yield, even with a reduction in the number of plants per area (Ferreira et al., 2018). High plant densities and small interrow spacings decrease the contribution of branches to grain yield, increasing the proportion of stems in the production. Therefore, branches are more significant for grain yield when lower sowing densities are associated with larger spacings (Procópio et al., 2014). Recent studies have shown that modern soybean cultivars, widely used in Brazil, continue to demonstrate high phenotypic plasticity (Luca \& Hungria, 2014; Balbinot Junior et al., 2015; Ferreira et al., 2016).

Soybean chemical composition (protein, oil, fatty acids, sugars, and minerals) may change when sowing density changes (Bellaloui et al., 2015). Bellaloui et al. (2014) evaluated four soybean cultivars at different densities and observed that the concentrations of protein, oleic acid, sugars, $P$, and $B$ decreased with a reduction in sowing density in the first growing season. However, an opposite effect was found in the second growing season, that is, the contents of protein and oleic acid decreased with an increase in sowing density. It indicates that the sowing density modifies the proportion of photoassimilates in branches and stems, which may interfere with the chemical composition of grains, but these effects depend on environmental conditions.

In this context, the impacts of a reduction in the soybean sowing density on the partition of photoassimilates between branches and stems and the percentage of protein and oil in the grains have been questioned. Thus, this study aimed to evaluate the yield components and contents of protein and oil in grains from branches and stems of two soybean cultivars as a function of the reduction in sowing density.

\section{Materials and Methods}

The experiments were carried out in the 2016/17 and $2017 / 18$ growing seasons in Londrina, PR, Brazil $\left(23^{\circ} 11^{\prime} \mathrm{S}\right.$ and $51^{\circ} 11^{\prime} \mathrm{W}$, with an altitude of $620 \mathrm{~m}$ ). The soil was classified as a highly clay-textured Oxisol (710, 82, and $208 \mathrm{~g} \mathrm{~kg}^{-1}$ of clay, silt, and sand, respectively) that had been managed under the no-tillage system for fifteen years. The soil had the following attributes in the 0 to $20 \mathrm{~cm}$ layer before setting up the experiments: $15.3 \mathrm{~g} \mathrm{dm}^{-3}$ of organic $\mathrm{C}, \mathrm{pH}\left(\mathrm{CaCl}_{2}\right)$ of $5.9,20.3 \mathrm{mg} \mathrm{dm}^{-3}$ of $\mathrm{P}$ (Mehlich-1), $0.56 \mathrm{cmol}_{\mathrm{c}} \mathrm{dm}^{-3}$ of exchangeable $\mathrm{K}, 5.2 \mathrm{cmol}_{\mathrm{c}} \mathrm{dm}^{-3}$ of exchangeable $\mathrm{Ca}, 2.6 \mathrm{cmol}_{\mathrm{c}}$ $\mathrm{dm}^{-3}$ of exchangeable $\mathrm{Mg}, 5.4 \mathrm{mg} \mathrm{dm}^{-3}$ of $\mathrm{S}$, and $70 \%$ of base saturation.

The experimental design was completely randomized blocks in a split-plot scheme, with five replications. Plots consisted of five sowing densities $(100,80,60,40$, and $20 \%$ of that indicated by the breeder) and subplots consisted of two plant strata (branches and stems). Two soybean cultivars with indeterminate growth habits and contrasting characteristics were evaluated. The soybean cultivar BRS 1010 IPRO has higher plant height, higher branching, and a relative maturity group of 5.9, whereas the cultivar NS 5959 IPRO has more compact plants, with a lower size and branching, and a maturity group of 6.1 .

The recommended sowing density range for the cultivars NS 5959 IPRO and BRS 1010 IPRO in the edaphoclimatic region in which the experiment was conducted is 380 to 420 and 265 to 310 thousand plants ha ${ }^{-1}$, respectively. The maximum values within the recommended range for each cultivar were considered to define the sowing densities. Thus, the treatments consisted of the following sowing densities 420, 336, 252, 168, and 84 thousand viable seeds ha-1 for NS 5959 IPRO and 310, 248, 186, 124, and 62 thousand viable seeds $\mathrm{ha}^{-1}$ for BRS 1010 IPRO.

The control of diseases, insect pests, and weeds were carried out according to the technical indications recommended for the soybean crop. The meteorological data were obtained at the Embrapa Soybean agrometeorological station, which is $500 \mathrm{~m}$ away from the experimental site, and were obtained during the period the experiments were conducted (Figure 1).

Sowing was carried out on October 31, 2016, and October 6,2017 , using a seed-cum-fertilizer drill equipped with lagged double-disc furrowers and perforated disc seed dosers with a double row of holes. The inter-row spacing was $45 \mathrm{~cm}$. Plots measured $10.0 \mathrm{~m}$ long and $5.0 \mathrm{~m}$ wide, totaling $50.0 \mathrm{~m}^{2}$. The useful area was $10.8 \mathrm{~m}^{2}$ ( $8.0 \mathrm{~m}$ long and $1.35 \mathrm{~m}$ wide).

Seeds were treated with Standak Top ${ }^{\circ}$ (pyraclostrobin + thiophanate-methyl + fipronil at doses of $150 \mathrm{~mL} 50 \mathrm{~kg}^{-1}$ seeds) and liquid inoculant Gelfix $5^{\circ}$ (Bradyrhizobium elkanii SEMIA 587 and SEMIA 5019 with $5 \times 10^{9}$ colony-forming units $\mathrm{mL}^{-1}$ at a dose of $100 \mathrm{~mL} 50 \mathrm{~kg}^{-1}$ seeds) at the sowing time.

Yield components were evaluated by cutting the plants close to the soil in 1.0 linear meter of each plot. The plants of each plot were then divided into stems and branches. The 

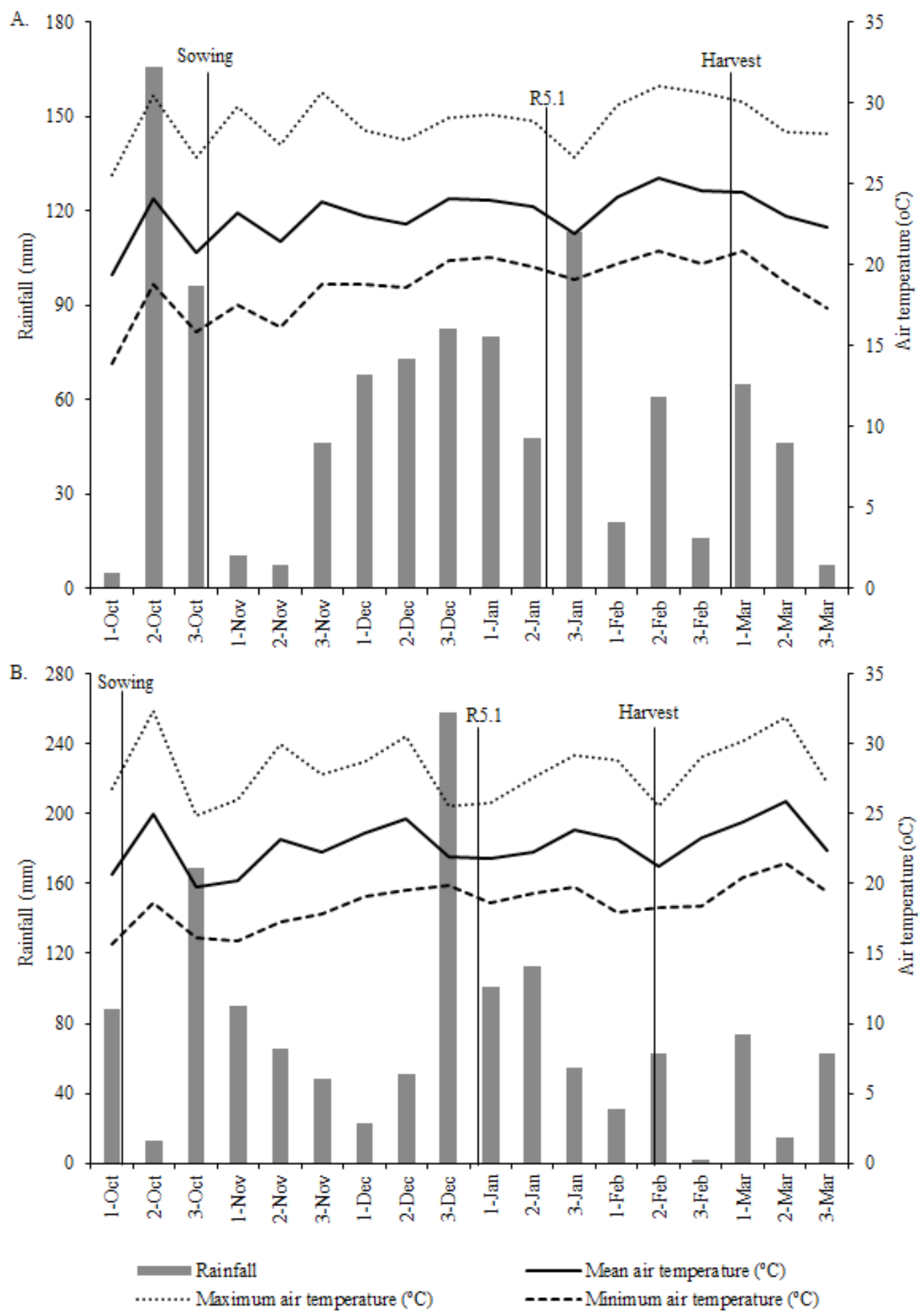

Figure 1. Rainfall and maximum, minimum and mean air temperature during the soybean development cycle in the growing seasons of 2016/2017 (A) and 2017/2018 (B). Londrina, PR, Brazil.

number of pods $\mathrm{m}^{-2}$, number of grains per pod, thousand grain weight, oil and protein contents, grain yield $\left(\mathrm{kg} \mathrm{ha}^{-1}\right)$, oil yield $\left(\mathrm{kg} \mathrm{ha}^{-1}\right)$, and protein yield $\left(\mathrm{kg} \mathrm{ha}^{-1}\right)$ were determined separately for stems and branches.

The number of pods per $\mathrm{m}^{-2}$ was determined by counting all pods present in the branches and stems of the collected plants, being then transformed into $\mathrm{m}^{-2}$. The number of grains per pod was obtained by counting all grains present in the branches and stems of the collected plants. After this stage, the number of grains per pod was obtained by dividing the number of grains by the number of pods in the branches and stems. The thousand-grain weight was determined by weighing two subsamples of 100 grains per replication, with results expressed in grams.

Oil and protein contents were determined in whole grains using the near-infrared reflectance (NIR) technique, as described by Heil (2010). The whole and clean grains were subjected to readings in a Thermo Antaris II, equipped with 
an integrating sphere with a resolution of $4 \mathrm{~cm}^{-1}$, an average of 32 scans, and background at each reading. Mathematical models developed by Embrapa Soybean were used to predict protein (180 standards, correlation coefficient $(r)=0.97$, root mean squared error of calibration $($ RMSEC $)=0.64)$ and oil contents (170 standards, $r=0.98$, and RMSEC $=0.45$ ).

Grain yield of branches and stems were estimated by multiplying the percentage of grain mass from stems and branches by the yield obtained in harvesting the entire useful area of the plots with moisture standardization at $13 \%$. Oil and protein yields were obtained by multiplying the grain yield by the percentage of oil or protein obtained in the grains divided by 100 . The results were transformed and expressed in $\mathrm{kg} \mathrm{ha}^{-1}$.

The data were analyzed for normality and homoscedasticity using the Shapiro-Wilk and Hartley tests, respectively, which indicated no need for data transformation. Subsequently, the data were subjected to analysis of variance and F-test. The means of branches and stems were compared by the F-test. A polynomial regression analysis up to the second degree was performed for sowing density. The error probability level of $5 \%$ was adopted for all analyses. The analyses were performed using the software Sistema para Análise de Variância - SISVAR.

\section{Results and Discussion}

Sowing density and plant strata showed an interaction for the number of pods per $\mathrm{m}^{-2}$, grain yield, protein yield, and oil
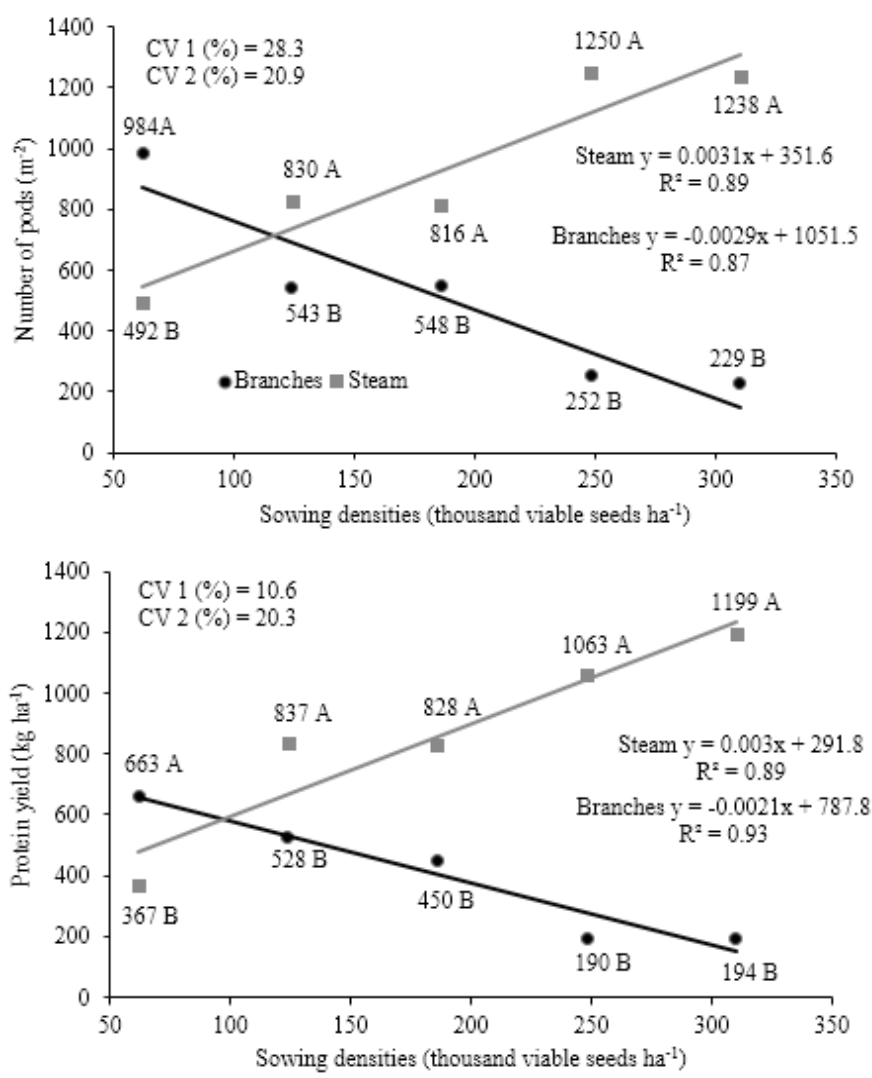

yield for both cultivars and evaluated growing seasons. The environmental conditions for soybean cultivation in the two analyzed growing seasons were adequate for soybean growth and development (Figure $1 \mathrm{~A}$ and $\mathrm{B}$ ).

The effect of sowing density within branches and stems was similar for all variables in both growing seasons and cultivars. The number of pods per $\mathrm{m}^{-2}$ and grains, protein, and oil yield increased in the branches as sowing density decreased. The reduction in sowing density caused a decrease in all variables for the stems. The increase in the number of plants per area led to a higher number of stems than branches and, therefore, the proportion of stems increases in the grain, protein, and oil yield (Ferreira et al., 2016).

The cultivar BRS 1010 IPRO in the 2016/17 growing season at the lowest evaluated sowing density ( $20 \%$ of that indicated by the breeder) showed the highest number of pods per $\mathrm{m}^{-2}$ and grain, protein, and oil yield in the branches compared to the stems (Figure 2), showing the high branching of this cultivar. Soybean plants under conditions of very low sowing densities have the ability to adapt to the environment, prioritizing the occupation of spaces and, therefore, emitting more branches, which is known as the phenotypic plasticity of the soybean crop (Thompson et al., 2015; Werner et al., 2016). The number of pods per $\mathrm{m}^{-2}$ and grain, protein, and oil productivities were higher for the stems than branches from a density of $40 \%$ of that indicated by the breeder. This result demonstrates that stems have a higher proportion in grain
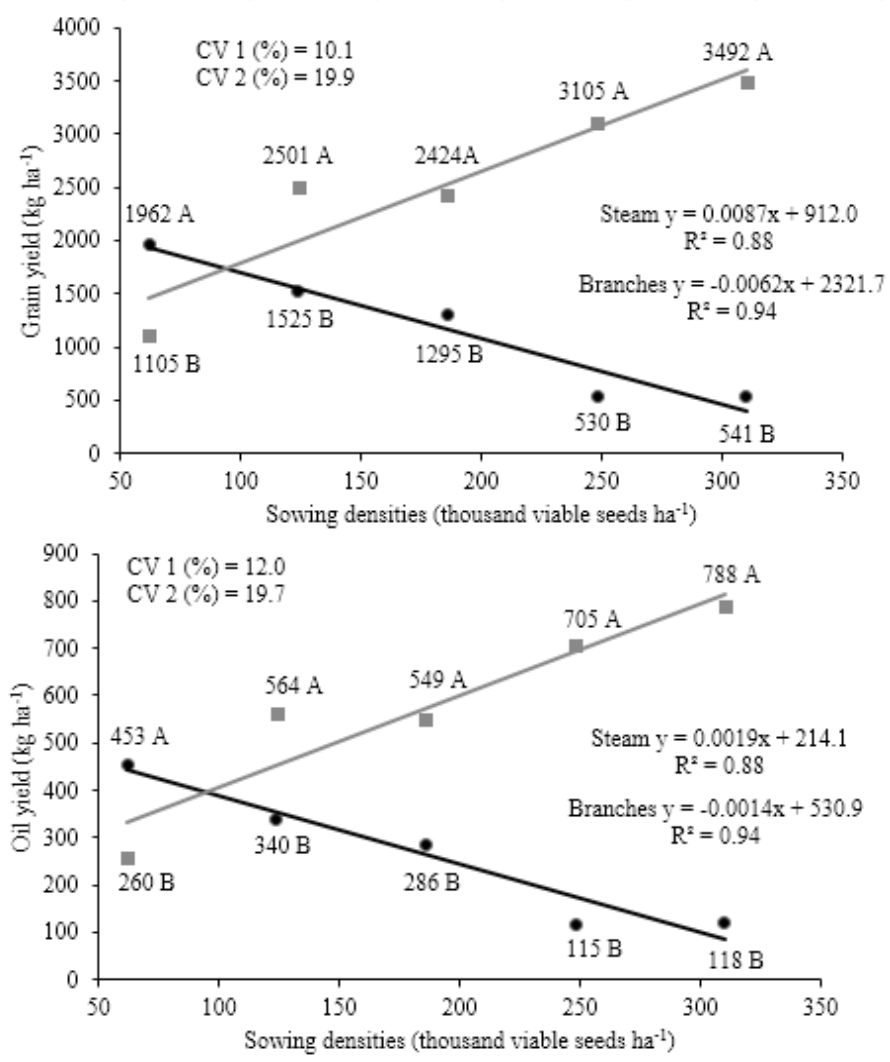

Figure 2. Number of pods $\mathrm{m}^{-2}$, grain yield $\left(\mathrm{kg} \mathrm{ha}^{-1}\right)$, protein yield $\left(\mathrm{kg} \mathrm{ha}^{-1}\right)$, and oil yield $\left(\mathrm{kg} \mathrm{ha}^{-1}\right)$ influenced by the interaction between sowing densities and plant strata of the cultivar BRS 1010 IPRO in the 2016/17 growing season, Londrina, PR, Brazil. CV 1: sowing density (plot); CV 2: stem and branches (subplot). 
production when plants have less space to occupy (Balbinot Junior et al., 2015).

The cultivar BRS 1010 IPRO in the $2017 / 18$ growing season showed no difference between branches and stems at the two lowest densities ( 20 and $40 \%$ of that indicated by the breeder) for all the analyzed variables (Figure 3 ). However, the stems presented the highest number of pods $\mathrm{m}^{-2}$ and grain, oil, and protein yield from the density of $60 \%$ of that indicated by the breeder (186 thousand viable seeds ha-1). It shows that the proportion of branches in grain, protein, and oil yield is essential at sowing densities far below that recommended by the breeder. The phenotypic plasticity of soybean in response to changes in sowing density corresponds to the genotype used and is greater under favorable environmental conditions during the growing period of the crop, expanding the productive potential of each plant (Cox \& Cherney 2011).

Unlike the cultivar BRS 1010 IPRO, the cultivar NS 5959 IPRO in the 2016/17 growing season showed no difference between branches and stems at the lowest density $(20 \%$ of that indicated by the breeder) for all variables (Figure 4). It demonstrates the lower branching capacity of the cultivar NA 5959 IPRO than BRS 1010 IPRO. The stems had the highest number of pods $\mathrm{m}^{-2}$ and grain, oil, and protein yield from the density of $40 \%$ of that indicated by the breeder (168 thousand viable seeds $\mathrm{ha}^{-1}$ ), showing that the proportion of the stems is higher than that of the branches with an increase in density. The low proportion of branches in grain production for plants
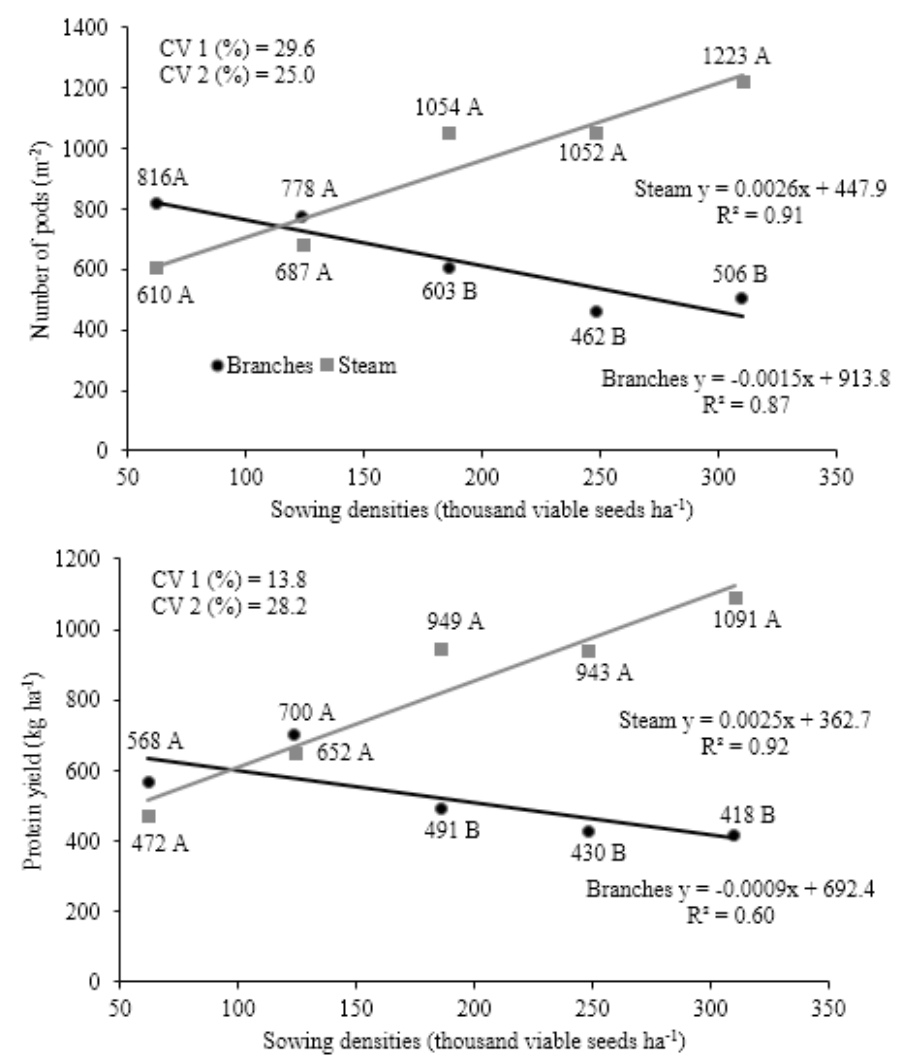

grown at higher sowing densities is probably due to the rapid closing of the canopy during vegetative growth, leading to an unfavorable environment to branching. Thus, production becomes more dependent on the stems (Ferreira et al., 2018).

The cultivar NS 5959 IPRO in the 2017/18 growing season showed a difference for the number of pods per $\mathrm{m}^{-2}$ at the lowest sowing density ( 84 thousand viable seeds ha ${ }^{-1}$ ), with branches presenting a higher amount of pods per $\mathrm{m}^{-2}$ than stems (Figure 5). However, no difference was observed between branches and stems at the two lowest densities (84 and 168 thousand viable seeds ha $^{-1}$ ) for grain, protein, and oil yield, which is due to the higher number of grains per pod in the stems than in the branches (Table 1). On the other hand, stems presented the highest values for all variables from the density of 252 thousand viable seeds ha ${ }^{-1}(60 \%$ of that recommended by the breeder), demonstrating the capacity of soybean plants to adapt to different conditions. Thus, the plants expressed characteristics of high plasticity as the soybean cycle progressed, that is, the plants adapted to environmental and management conditions, modifying their morphology, especially when emitting a high number of long and productive branches at low densities sowing (Holtz et al. 2014). The adequate water supply observed in both growing seasons (Figure 1), enabled the phenotypic plasticity expression of the evaluated cultivars.

The cultivar BRS 1010 IPRO in the 2016/17 growing season had an effect of plant strata and sowing density for the
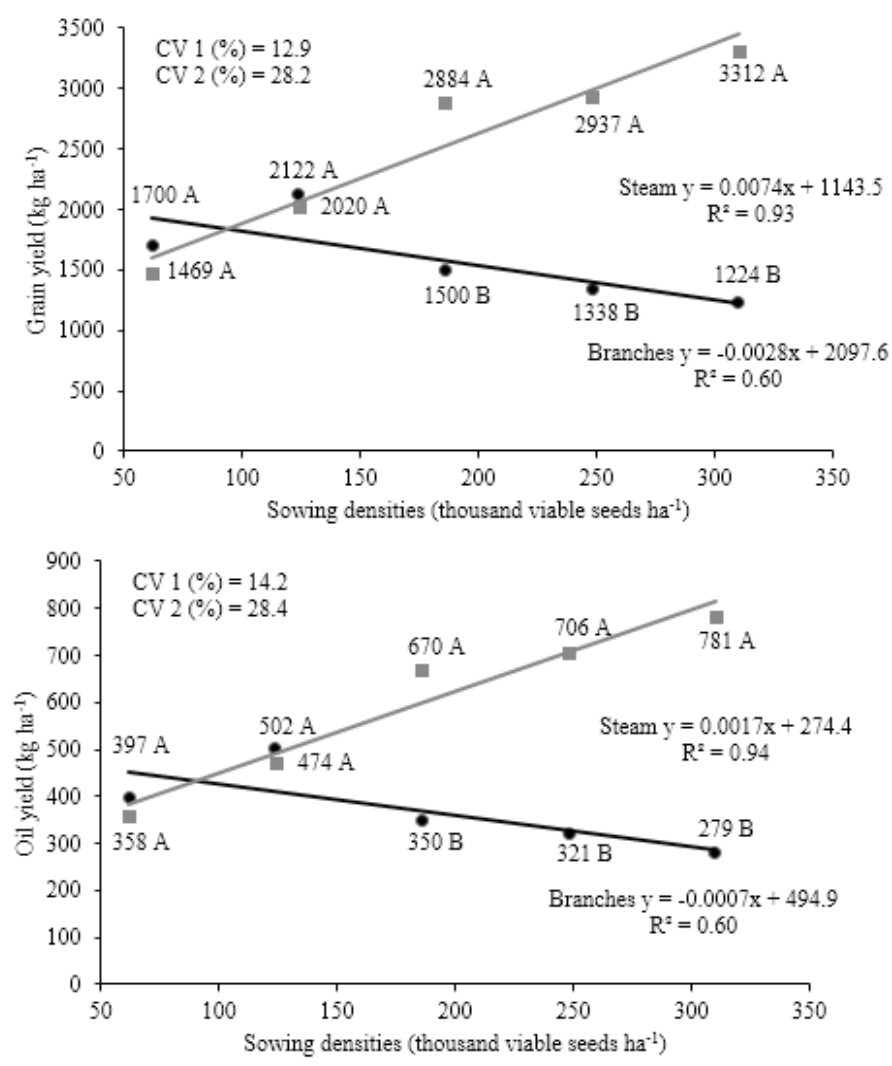

Figure 3. Number of pods $\mathrm{m}^{-2}$, grain yield $\left(\mathrm{kg} \mathrm{ha}^{-1}\right)$, protein yield $\left(\mathrm{kg} \mathrm{ha}^{-1}\right)$, and oil yield $\left(\mathrm{kg} \mathrm{ha}^{-1}\right)$ influenced by the interaction between sowing densities and plant strata of the cultivar BRS 1010 IPRO in the 2017/18 growing season, Londrina, PR, Brazil. CV 1: sowing density (plot); CV 2: stem and branches (subplot). 

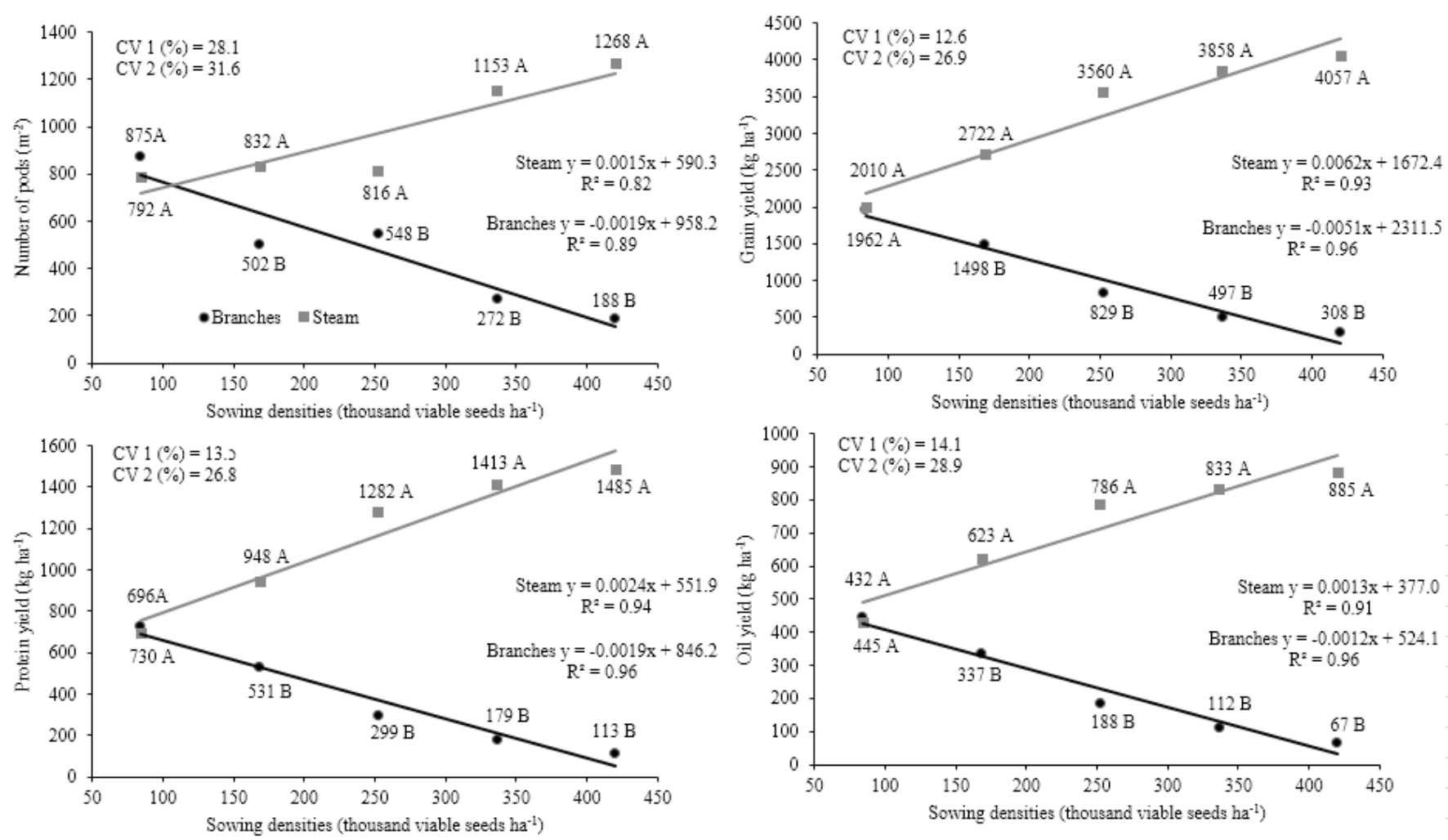

Figure 4. Number of pods $\mathrm{m}^{-2}$, grain yield $\left(\mathrm{kg} \mathrm{ha}^{-1}\right)$, protein yield $\left(\mathrm{kg} \mathrm{ha}^{-1}\right)$, and oil yield $\left(\mathrm{kg} \mathrm{ha}^{-1}\right)$ influenced by the interaction between sowing densities and plant strata of the cultivar BRS 5959 IPRO in the 2016/17 growing season, Londrina, PR, Brazil. CV 1: sowing density (plot); CV 2: stem and branches (subplot).
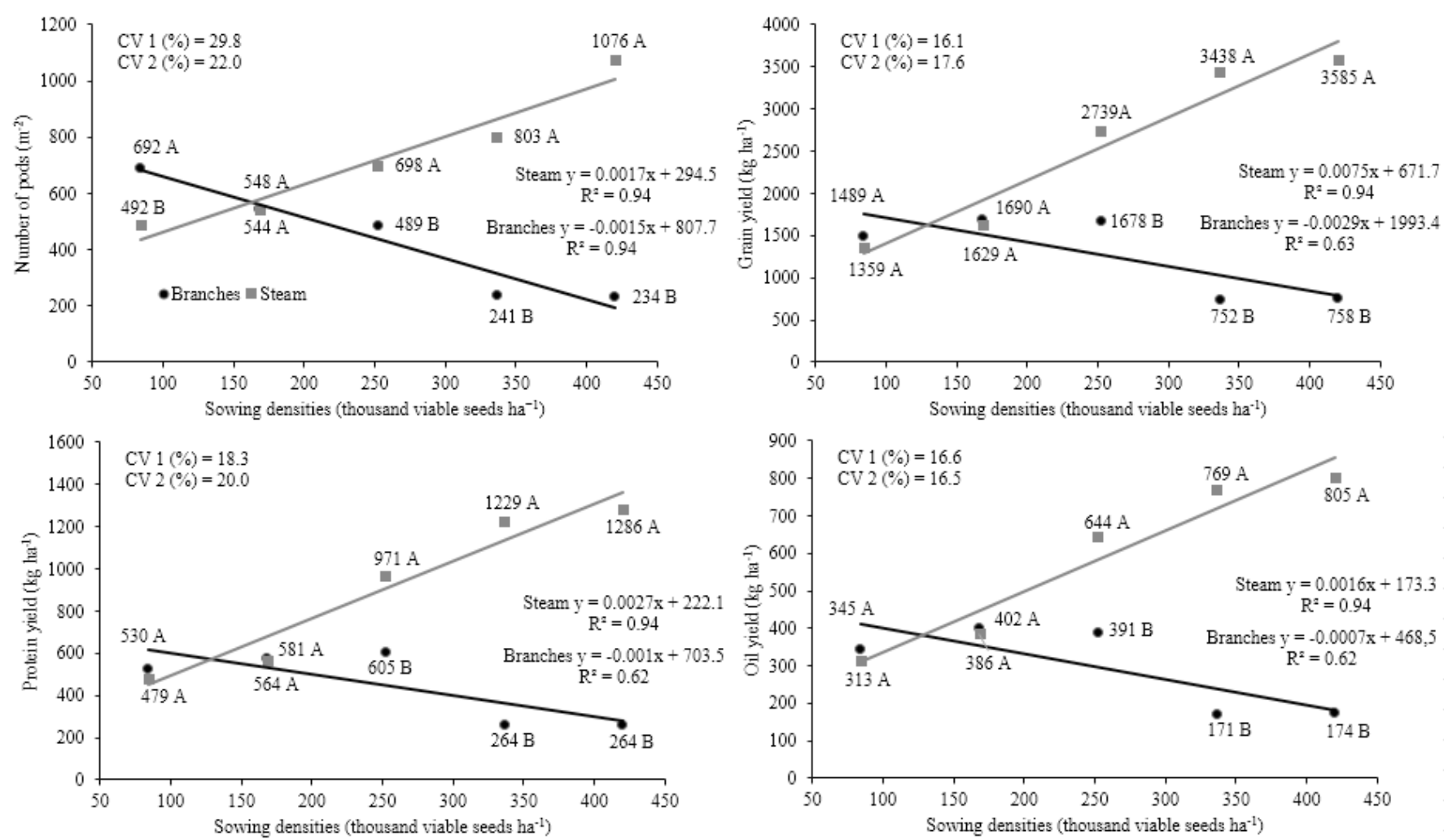

Figure 5. Number of pods $\mathrm{m}^{-2}$, grain yield $\left(\mathrm{kg} \mathrm{ha}^{-1}\right)$, protein yield $\left(\mathrm{kg} \mathrm{ha}^{-1}\right)$, and oil yield $\left(\mathrm{kg} \mathrm{ha}^{-1}\right)$ influenced by the interaction between sowing densities and plant strata of the cultivar BRS 5959 IPRO in the 2017/18 growing season, Londrina, PR, Brazil. CV 1: sowing density (plot); CV 2: stem and branches (subplot). 
Tabela 1. Number of grains per pod, thousand grain weight (grams), protein yield (kg ha ${ }^{-1}$ ), and oil yield (kg ha-1) only influenced by sowing densities and plant strata, Londrina, PR.

\begin{tabular}{|c|c|c|c|c|}
\hline Plant strata & $\begin{array}{c}\text { Number of grains } \\
\text { per pod }\end{array}$ & $\begin{array}{c}\text { Thousand grain } \\
\text { weight }\end{array}$ & Protein (\%) & Oil (\%) \\
\hline \multicolumn{5}{|c|}{ 2016/17 growing season - BRS 1010 IPRO } \\
\hline Branches & $2.27 \mathrm{~B}^{1}$ & $131.1 \mathrm{~A}$ & $34.9 \mathrm{~A}$ & $22.2 \mathrm{~A}$ \\
\hline Fitted equation & $\hat{Y}=1 E-11 x^{2}-5 E-06 x+2.8706$ & ns & $\hat{Y}=6 E-06 x+33.175$ & ns \\
\hline $\mathrm{R}^{2}$ & 0.44 & - & 0.57 & - \\
\hline \multicolumn{5}{|c|}{ 2017/18 growing season - BRS 1010 IPRO } \\
\hline Branches & $2.28 \mathrm{~B}$ & $143.1 \mathrm{~A}$ & $33.1 \mathrm{~A}$ & $23.4 \mathrm{~A}$ \\
\hline Steam & $2.47 \mathrm{~A}$ & $140.0 \mathrm{~A}$ & $32.5 \mathrm{~B}$ & $23.7 \mathrm{~A}$ \\
\hline Fitted equation & ns & ns & ns & ns \\
\hline $\mathrm{R}^{2}$ & - & - & - & - \\
\hline CV $1(\%)$ & 8.2 & 8.2 & 4.3 & 5.2 \\
\hline \multicolumn{5}{|c|}{ 2016/17 growing season - NS 5959 IPRO } \\
\hline Steam & $2.49 \mathrm{~A}$ & $150.0 \mathrm{~A}$ & $35.9 \mathrm{~A}$ & $22.0 \mathrm{~A}$ \\
\hline Fitted equation & ns & $\hat{Y}=140.47+0.0264 x$ & $\hat{\gamma}=35.15+0.0036 x$ & ns \\
\hline $\mathrm{R}^{2}$ & - & 0.87 & 0.76 & - \\
\hline CV $1(\%)$ & 9.1 & 4.5 & 2.8 & 3.3 \\
\hline CV $2(\%)$ & 5.2 & 5.7 & 2.4 & 3.6 \\
\hline \multicolumn{5}{|c|}{ 2017/18 growing season - NS 5959 IPRO } \\
\hline Branches & $2.16 \mathrm{~B}$ & $160.1 \mathrm{~A}$ & $35.2 \mathrm{~A}$ & $23.2 \mathrm{~A}$ \\
\hline Steam & $2.49 \mathrm{~A}$ & $160.2 \mathrm{~A}$ & $35.3 \mathrm{~A}$ & $23.1 \mathrm{~A}$ \\
\hline Fitted equation & $\hat{Y}=2.611-0.0011 x$ & $\hat{Y}=147.46+0.0502 x$ & ns & ns \\
\hline $\mathrm{R}^{2}$ & 0.75 & 0.63 & - & - \\
\hline CV $1(\%)$ & 13.3 & 8.0 & 4.8 & 4.4 \\
\hline
\end{tabular}

${ }^{1}$ Means followed by the same letters in the row do not differ at 0.05 probability level by F test. CV 1: Sowing density (plot); CV 2: stem and branches (subplot).

number of grains per pod and protein content of grains (Table 1). The decrease in sowing density provided an increase in the number of grains per pod due to an increase in the availability of resources for each plant (Ferreira et al., 2016). The branches showed a lower number of grains per pod than the stems. Procópio et al. (2013) also observed that the number of grains per pod in the branches was more influenced by the sowing density than the number of grains per pod in the stems. Thus, an important compensatory response of soybean plants given the reduced number of individuals by area was the increase in the number of grains per pod, as also observed by Ferreira et al. (2016).

The first growing season showed a decrease in the protein content of grains with a reduction in sowing density and higher content in the branches than the stems in the cultivar BRS 1010 IPRO (Table 1). Similarly, Bellaloui et al. (2015) reported that the increase in sowing density promotes an increase in the protein concentration of soybean. It occurs because the production of each plant is lower at higher sowing densities, allowing that each plant to supply the number of grains produced, providing higher protein contents. However, high soybean densities (above 500 thousand plants ha ${ }^{-1}$ ) may lead to a deficiency in grain filling due to excessive intraspecific competition for water, light, and nutrients (Ferreira et al., 2016). In this sense, Bellaloui et al. (2014) concluded that the chemical composition of grains depends on the sowing density, inter-row spacings, genotypes, and mainly the environmental growth conditions for each year, particularly temperature and drought.

The cultivar BRS 1010 IPRO in the 2017/18 growing season showed an isolated effect of branches and stems for protein content and the number of grains per pod (Table 1). Also, this cultivar showed a higher number of grains in the stems than in the branches in the 2016/17 growing season. It can be explained by the high demand for photoassimilates from the stems compared to the branches (Balbinot Junior et al., 2015). As in the 2016/17 growing season, branches showed an increase in protein content compared to the stems.

The cultivar NS 5959 IPRO in the 2016/17 growing season had the thousand-grain weight influenced by the plant strata and sowing density. The thousand-grain weight decreased as the sowing density was reduced, with a higher decrease for stems than branches. The demand force of plants at higher sowing densities is directed to the stems, as there is little competition with branches (Werner et al., 2016). Thus, stems are better supplied by photoassimilates at higher plant densities and, consequently, the grains from these structures, providing a higher grain mass (Balbinot Junior et al., 2015). Additionally, according to Kuss et al. (2008) and Balbinot Junior et al. (2016), the increase in sowing density leads to 
higher root growth at depth, increasing the water absorption capacity in subsurface layers, allowing better water supply to plants during the grain-filling period.

The protein content of the cultivar NS 5959 IPRO in the 2016/17 growing season showed an isolated effect of sowing density, leading to a decrease in the protein content of grains. Higher plant densities provide a better supply of grains for each individual, thus prioritizing the grain-filling quality. Werner et al. (2017) evaluated three sowing densities (150, 300 , and 450 thousand viable seeds ha $\mathrm{a}^{-1}$ ) and also observed an increase in the protein content of grains with an increase in sowing density.

The cultivar NS 5959 IPRO in the 2017/18 growing season showed an effect of branches and stems only for the number of grains per pod, as observed in the 2016/17 growing season for this cultivar, which had branches with a lower number of grains per pod. Overall, the results obtained in the present research indicate that the number of grains per pod is more influenced by the plant strata (stem or branches) than the grain mass.

The number of grains per pod and thousand-grain weight had an isolated effect of sowing density. A reduction in sowing density led to an increase in the number of grains per pod and a decrease in thousand-grain weight. This reduction in sowing density was expected to increase the thousand-grain weight due to a decrease in the intraspecific competition for resources available in the environment (water, light, and nutrients) (Luca \& Hungria, 2014). Ferreira et al. (2016) tested different sowing densities (150 to 560 thousand viable seeds $\mathrm{ha}^{-1}$ ) and also observed a decrease in thousand-grain weight with a reduction in sowing density.

The oil content in both cultivars and growing seasons was not influenced by the experimental factors, showing values around $22-23 \%$. It demonstrates that the oil content is little affected by the sowing density and plant strata when the environmental conditions are favorable to plant development, as observed in the present study (Figure 1) (Moreira et al., 2015; Sultan et al., 2015).

\section{Conclusions}

The number of pods $\mathrm{m}^{-2}$ and grain, protein, and oil yield increased in the branches and decreased in the stems with a decrease in sowing density.

The number of grains per pod was higher in the stems than in the branches, regardless of the cultivar, but the effect of sowing density on this variable depends on the growing season and cultivar.

The protein content in the grains is higher in branches than stems for the cultivar BRS 1010 IPRO and decreased with a reduction in sowing density.

The thousand-grain weight of the cultivar NS 5959 IPRO decreased with a reduction in sowing density.

The oil content in the grains was not influenced by the plant strata (stems and branches) and the decrease in sowing density.

\section{Compliance with Ethical Standards}

Funding: The Brazilian National Council for Scientific and Technological Development (CNPq) and, the Coordination for the Improvement of Higher Education Personnel (CAPES) for granting doctoral scholarships to the first and third authors, respectively.

Conflict of interest: The authors declare no conflict of interest.

Author contribution: Conceptualization: WF, FAS, BJAA, ZC, ASMA; Data curation: WF, FAS; Formal analysis: WF, FAS, BJAA; Funding acquisition: BJAA, ZC, ASMA; Investigation: WF, FAS; Methodology: WF, FAS, BJAA; Project administration: BJAA, ZC, ASMA; Resources: BJAA, ZC, ASMA; Supervision: BJAA, ZC, ASMA; Validation: WF, FAS, BJAA; Visualization: WF, FAS, BJAA, ZC, ASMA; Writing - original draft: WF, BJAA; Writing - review \& editing: WF, FAS, BJAA, ZC, ASMA..

\section{Literature Cited}

Balbinot Junior, A. A.; Procópio, S. O.; Debiasi, H.; Franchini, J. C.; Panison, F. Semeadura cruzada em cultivares de soja com tipo de crescimento determinado. Semina Ciências Agrárias, v. 36, n.3, p.1215-1226, 2015. https://doi.org/10.5433/16790359.2015v36n3p1215.

Balbinot Junior, A. A.; Procópio, S. O.; Neumaier, N.; Ferreira, A. S.; Werner, F.; Debiasi, H.; Franchini, J. C. Semeadura cruzada, espaçamento entre fileiras e densidade de semeadura influenciando o crescimento e a produtividade de duas cultivares de soja. Revista de Ciências Agroveterinárias, v.15, n.2, p.83-93, 2016. https://doi.org/10.5965/223811711522016083.

Balbinot Junior, A.A.; Oliveira, M. C. N.; Zucareli, C.; Ferreira, A. S.; Werner, F.; Aguiar e Silva, M. A. Analysis of phenotypic plasticity in indeterminate soybean cultivars under different row spacing. Australian Journal of Crop Science, v.12, n.4, p.648-654, 2018. https://doi.org/10.21475/ajcs.18.12.04.pne1003.

Bellaloui, N.; Bruns, H. A.; Abbas, H. K.; Mengistu, A.; Fisher, D. K.; Reddy, K. N. Agricultural practices altered soybean seed protein, oil, fatty acids, sugars, and minerals in the Midsouth USA. Frontiers in Plant Science, v.31, n.6, p.1-14, 2015. https://doi. org/10.3389/fpls.2015.00031.

Bellaloui, N.; Mengistu, A.; Walker, E.R.; Young, L.D. Soybean seed composition as affected by seeding rates and row spacing. Crop Science, v.54, n.4, p.1782-1795, 2014. https://doi.org/10.2135/ cropsci2013.07.0463.

Board, J.E.; Kahlon, C.S. Morphological responses to low plant population differ between soybean genotypes. Crop Science, v.53, n.3, p.1109-1119, 2013. https://doi.org/10.2135/ cropsci2012.04.0255.

Büchling, C.; Oliveira Neto, A. M.; Guerra, N.; Bottega, E. L. Uso da plasticidade fenotípica como estratégia para a redução da população de plantas em cultivares de soja. Revista Agrarian, v.10, n.35, p.22-30, 2017. https://doi.org/10.30612/agrarian. v10i35.3931. 
Corassa, G. M.; Amado, T. J. C.; Strieder, M. L.; Schwalbert, R.; Pires, J. L. F.; Carter, P. R.; Ciampitti, I. A. Optimum Soybean Seeding Rates by Yield Environment in Southern Brazil. Agronomy Journal, v.110 n.6, p.2430-2438, 2018. https://doi.org/10.2134/ agronj2018.04.0239.

Cox, W.J.; Cherney, J.H. Growth and yield responses of soybean to row spacing and seeding rate. Agronomy Journal, v.103, n.1, p.123-128, 2011. https://doi.org/10.2134/ agronj2010.0316.

De Bruin, J.L.; Pedersen, P. Effect of row spacing and seeding rate on soybean yield. Agronomy Journal, v.100, n.3, p.704-10, 2008. https://doi.org/10.2134/agronj2007.0106.

Ferreira, A.S.; Balbinot Junior, A.A.; Werner, F.; Zucareli, C. Plant spatial arrangement affects grain production from branches and stem of soybean cultivars. Bragantia, v.77, n.4, p.567-576, 2018. https://doi.org/10.1590/1678-4499.201728.

Ferreira, A.S; Balbinot Junior, A.A.; Werner, F.; Zucareli, C.; Franchini, J. C.; Debiasi, H. Plant density and mineral nitrogen fertilization influencing yield, yield components, and concentration of oil and protein in soybean grains. Bragantia, v.75, n.3, p. 362-370, 2016. https://doi.org/10.1590/1678-4499.479.

Gaspar, A.P.; Conley, S.P. Responses of canopy reflectance, light interception, and soybean seed yield to replanting suboptimal stands. Crop Science, v.55, p.377-385, 2015. https://doi. org/10.2135/cropsci2014.03.0200.

Heil, C. Rapid, multi-component analysis of soybeans by FT-NIR Spectroscopy. Madison: Thermo Fisher Scientific, 2010. 3p. (Application note: 51954). https://www.thermoscientific. com/content/dam/tfs/ATG/CMD/CMD\%20Documents/ Application\%20\&\%20Technical\%20Notes/AN-51954-RapidMulti-Component-Analysis-Soybeans-AN51954-EN.pdf. 20 Jun. 2019.

Holtz, V.; Couto, R.F.; Oliveira, D.G.; Reis, E.F. Deposição de calda de pulverização e produtividade da soja cultivada em diferentes arranjos espaciais. Ciência Rural, v.44, n.8, p.1371-1376, 2014. https://doi.org/10.1590/0103-8478cr20130783.

Kuss, R.C.R.; Konig, O.; Dutra, L.M.C.; Bellé, R.A.; Roggia, S.; Sturmer, G.R. Populações de plantas e estratégias de manejo da irrigação na cultura da soja. Ciência Rural, v.38, n.4, p.1133-1137, 2008. https://doi.org/10.1590/S0103-84782008000400036.
Lee, C.D.; Egli, D.B.; Tekrony, D.M. Soybean response to plant population at early and late planting dates in the Mid-South. Agronomy Journal, v.100, n.4, p.971-976, 2008. https://doi. org/10.2134/agronj2007.0210.

Luca, M. J.; Hungria, M. Plant densities and modulation of symbiotic nitrogen fixation in soybean. Scientia Agricola, v.71, n.3, p.181187, 2014. https://doi.org/10.1590/S0103-90162014000300002.

Moreira, A.; Moraes, L.A.C.; Schroth, G.; Mandarino, J.M.G. Effect of nitrogen, row spacing, and plant density on yield, yield components, and plant physiology in soybean-wheat intercropping. Agronomy Journal, v.107, n.6, p.2162-2170, 2015 https://doi.org/10.2134/agronj15.0121.

Procópio, S.O.; Balbinot Junior, A.A.; Debiasi, H.; Franchini, J.C.; Panison, F. Plantio cruzado na cultura da soja utilizando uma cultivar de hábito de crescimento indeterminado. Amazonian Journal: Revista de Ciências Agrárias, v.56, n.4, p.319-325, 2013 https://doi.org/10.4322/rca.2013.048.

Procópio, S.O.; Balbinot Junior, A.A.; Debiasi, H.; Franchini, J.C.; Panison, F. Semeadura em fileira dupla e espaçamento reduzido na cultura da soja. Agro@mbiente Online, v.8, n.2, p.212-221, 2014. https://doi.org/10.18227/1982-8470ragro.v8i2.1469.

Sultan, S. M.; Dikshit, M.; Vaidya. U.J. Oil content and fatty acid composition of soybean (Glycine max L.) genotypes evaluated under rainfed conditions of Kashmir Himalayas in India. Journal of Applied and Natural Science, v. 7, n. 2, p. 910-915, 2015. https://doi.org/10.31018/jans.v7i2.706.

Thompson, N.M.; Larson, J.A.; Lambert, D.M.; Roberts, R.K.; Mengistu, A.; Bellaloui, N.; Walker, E.R. Mid-south soybean yield and net return as affected by plant population and row spacing. Agronomy Journal, v.107, n.3, p. 979-989, 2015. https://doi. org/10.2134/agronj14.0453.

Werner, F.; Balbinot Junior, A.A.; Ferreira, A.S.; Aguiar e Silva, M.A.; Debiasi, H.; Franchini, J.C. Soybean growth affected by seeding rate and mineral nitrogen. Revista Brasileira de Engenharia Agrícola e Ambiental, v.20, n. 8, p. 734-738, 2016. https://doi. org/10.1590/1807-1929/agriambi.v20n8p734-738.

Werner, F.; Balbinot Junior, A.A.; Ferreira, A.S.; Aguiar e Silva, M.A.; Mandarino, J.M.G.; Zucareli, C. Size, chlorophyll retention and protein and oil contents of grains from soybean plants grown in different spatial arrangements. Semina: Ciências Agrárias, v. 38, n. 1, p. 85-96, 2017. https://doi.org/10.5433/1679-0359.2017v38n1p85. 